\title{
Halacarid mites of the genus Agauopsis (Acari: Halacaridae) from West Coast of Antalya, Turkey
}

\section{Batı Antalya (Türkiye) sahilinden Agauopsis (Acari: Halacaridae) cinsine ait halacaridler}

\author{
Furkan Durucan $^{1 *}$ (D) Yunus Ömer Boyacı² \\ 1 Işıklar Caddesi No 16,17 TR-07100 Antalya, Turkey \\ ${ }^{2}$ Süleyman Demirel University, Eğirdir Fisheries Faculty, Isparta, Turkey \\ *Corresponding author:f_durucan@hotmail.com
}

How to cite this paper:

Durucan, F. \& Boyacı, Y.O.. (2018). Halacarid mites of the genus Agauopsis (Acari: Halacaridae) from West Coast of Antalya, Turkey. Ege Journal of Fisheries and Aquatic Sciences, 35(1): 49-53. doi:10.12714/egejfas.2018.35.1.09

\begin{abstract}
Five Agauopsis species were determined at 8 sampling stations, various depths and habitats in the West Mediterranean Sea Coast of Antalya, Turkey. Among them Agauopsis nonornata is new for the Mediterranean Sea, Agauopsis brevipalpus, Agauopsis conjuncta, Agauopsis ibssi and Agauopsis pteropes are new for the Eastern Mediterranean Sea. Each species is illustrated, briefly described here with their worldwide geographical distributions and habitat informations.

Keywords: Acari, Halacaridae, Agauopsis, Turkey, Antalya

Öz: Bu çalışmada, Antalya'nın Batı Akdeniz kıyılarındaki 8 istasyonda çeşitli derinlik ve habitatlardan 5 Agauopsis türü tespit edilmiştir. Bu türlerden Agauopsis nonornata, Akdeniz için, Agauopsis brevipalpus, Agauopsis conjuncta, Agauopsis ibssi ve Agauopsis pteropes Doğu Akdeniz kıyıları için yenidir. Her bir türün illustrasyonları yapıımış, kısa tanımları, habitat bilgileri ve dünyadaki dağılımları verilmiştir.
\end{abstract}

Anahtar kelimeler: Acari, Halacaridae, Agauopsis, Türkiye, Antalya

\section{INTRODUCTION}

Halacaridae is a family of aquatic (freshwater, brackish and marine) ecosystems, meiobenthic and covered by chitinous cuticle. To date, about 1120 species of halacarids have been reported worldwide, from habitats including macroalgae, sponge colonies, hydrozoans, bryozoans, barnacles, mussels, polychaetes, mud, and sandy habitats (Bartsch, 2006). They live in sediments from the littoral zone to the deep sea (Bartsch, 1989). The family are distributed on 64 genera. Of them Agauopsis Viets is the one of the richest in genera which has more than 80 species (WoRMS, 2017).

\section{MATERIALS AND METHODS}

Sandy deposits (detritus-riched, fine to coarse), various macroalgae, marine phanerogams (Cymodosa nodosa and Posidonia oceanica), bivalves (Mytilus galloprovincilalis and Ostrea sp.) samples were collected by hand intertidally or various depths $(0-30 \mathrm{~m})$ usually using SCUBA or snorkelling diving at localities along the West Coast of Antalya. Immediately after collection, mites were extracted by washing the substrates. The meiofauna retained in the set of sieves (63 $\mu \mathrm{m}, 500 \mu \mathrm{m}, 1 \mathrm{~mm}$ ) was sorted under binocular microscope (Nikon SMZ 10A). In the laboratory, mite specimens were cleared in lactic acid and mounted in glycerine jelly. Figures were drawn with the aid of a camera lucida (Nikon Eclipse E400). The specimens were kept in the first author's personal collection in Antalya.

The following abbreviations used in the text and figure legends: $A D$, anterior dorsal plate; $A E$, anterior epimeral plate; $\mathrm{dp}-1$ to $\mathrm{dp}-4$,dorsal gland pores numbered from anterior to posterior; ds- 1 to ds-6, dorsal setae (excluding those on posterior epimeral plate) numbered in sequence from anterior to posterior; GA, genitoanal plate; GO, genital opening; OC, ocular plate; $\mathrm{PD}$, posterior dorsal plate; $\mathrm{PE}$, posterior epimeral plate; P-2 to P-4, second to fourth palpal segments; I-IV, leg I to leg IV.

\section{RESULTS}

A total of 152 Agauopsis specimens belonging to five species were found along the West Mediterranean Sea Coast 
of Antalya, Turkey: Agauopsis brevipalpus (137 indiv.), Agauopsis conjuncta (8 indiv.), Agauopsis ibssi (2 indiv.), Agauopsis nonornata (2 indiv.) and Agauopsis pteropes (3 indiv.). The descriptions of the species that will be presented as follows:

$\begin{array}{llll}\text { Systematics } & & & \\ \text { Class } & \text { ARACHNIDA } & \text { Cuvier, } & 1812 \\ \text { Subclass } & \text { ACARI } & \text { Leach, } & 1817 \\ \text { Family } & \text { HALACARIDAE } & \text { Murray, } & 1877\end{array}$

\section{Genus AGAUOPSIS, Viets, 1927}

Aguopsis brevipalpus (Trouessart, 1889) Figs. 1,2,11,12

Material examined: Ten females, five males among Corallina officinalis ( $2 \mathrm{~m}$ depth), Jania rubens $(3 \mathrm{~m})$ at Örnekköy Beach $\left(36^{\circ} 50^{\prime} 49^{\prime \prime} \mathrm{N} ; 30^{\circ} 48^{\prime} 18^{\prime \prime} \mathrm{E}\right)$; twenty females, seventeen males, four deutonymphs and two protonymphs among Amphiora rigida ( $3 \mathrm{~m})$, C. officinalis and J. rubens $(1 \mathrm{~m})$, Laurencia viscida $(6 \mathrm{~m})$ at Yakamoz Beach $\left(36^{\circ} 50^{\prime} 44^{\prime \prime} \mathrm{N} ; 30^{\circ} 47^{\prime} 57^{\prime \prime E}\right)$; two females, two males from fine sand $(5 \mathrm{~m})$ at Bilem Beach $\left(36^{\circ} 51^{\prime} 17^{\prime \prime} \mathrm{N} ; 30^{\circ} 44^{\prime} 38^{\prime \prime} \mathrm{E}\right)$; twelve females from Cystoseria barbata, Ostrea sp., Mytilus galloprovincialis $(5 \mathrm{~m})$ at Kemer $\left(36^{\circ} 35^{\prime} 566^{\prime \prime} \mathrm{N}\right.$; $\left.30^{\circ} 34^{\prime} 29^{\prime \prime} \mathrm{E}\right)$; six females, four males, two deutonymphs from $C$. officinalis $(3 \mathrm{~m})$, C. barbata, $(7 \mathrm{~m})$ at Faselis $\left(36^{\circ} 31^{\prime} 30^{\prime \prime} \mathrm{N} ; 30^{\circ} 33^{\prime} 8 \mathrm{E}\right)$; eleven females, six males from Galaxura oblongata $(2 \mathrm{~m})$, J. rubens $(5 \mathrm{~m})$ at Finike $\left(36^{\circ} 16^{\prime} 44 " \mathrm{~N}\right.$; $\left.30^{\circ} 8^{\prime} 25^{\prime \prime} \mathrm{E}\right)$; twelve males from Mesophyllum expansum (10m) at Kaş ( $\left.36^{\circ} 9^{\prime} 25^{\prime \prime} \mathrm{N} ; 29^{\circ} 37^{\prime} 42^{\prime \prime} \mathrm{E}\right)$; twenty two females from Bryopsis plumosa, Cladophora sp. (1m), Padina pavonica (3m) at Kalkan (36 $\left.15^{\circ} 43^{\prime \prime} \mathrm{N} ; 29^{\circ} 24^{\prime} 41.54^{\prime \prime} \mathrm{E}\right)$.

Short description: Length of females $330-525 \mu \mathrm{m}$, of males 300-400 $\mu \mathrm{m}$. Length of deutonymphs 350-390 $\mu \mathrm{m}$, protonymphs $280-290 \mu \mathrm{m}$ long. Idiosoma wide and heavily armed in adults. $A D$ and $P D$ with slightly raised longitudinal costae; costae with canaliculi. AD with small frontal process and with distincly raised H-like costa. Gland pores small. ds-2, ds- 3 and ds- 4 are small and their position on integument of idiosoma. ds- 5 on PD. AD of female $175 \mu \mathrm{m}$ long, $150 \mu \mathrm{m}$ wide and has one pair of gland pores. Pair of ds-1 level with gland pore on AD. OC of female $95 \mu \mathrm{m}$ long, $90 \mu \mathrm{m}$ wide, with two cornea. OC with rounded angles. PD of female $200 \mu \mathrm{m}$ long, $175 \mu \mathrm{m}$ wide. AE of female $200 \mu \mathrm{m}$ long, $370 \mu \mathrm{m}$ wide. PE of female $200 \mu \mathrm{m}$ long, $75 \mu \mathrm{m}$ wide. GA of female $150 \mu \mathrm{m}$ long, $175 \mu \mathrm{m}$ wide. Female $\mathrm{GA}$ with 3 pairs of perigenital setae. Gnathosoma $200 \mu \mathrm{m}$ long, $112 \mu \mathrm{m}$ wide, slender. Total palp lenght is $125 \mu \mathrm{m}$. Rostrum about as long as gnathosomal base. Leg I much wider and longer than adjoining segments. Telofemur I, 2.5 times longer than high, with two ventral spines (Figs. 1, 2, 11 \& 12).

Distribution: A. brevipalpus is one of the most encountered species in the genus of Agauopsis. It has been commonly found on the coast of North Atlantic and its adjacent basins (Mediterranean Sea, Black Sea) (Bartsch, 2009). It was recorded first time from Turkey, (Black Sea-Sinop) by Bartsch
(2004). In this study, we recorded it from Antalya, Turkey. This is the second record from Turkey.

Remarks: With regard to the external morphological characters, the specimens are correspond with Black Sea (Sevastapol) (Bartsch, 1996) and Mediterranean Sea (Croatia) (Viets, 1940) specimens.

Agauopsis conjuncta Viets, 1940

Figs. $3,4,13,14$

Material examined: Four females, four males from Cymodocea nodosa (15 m) at Kaş ( $\left.36^{\circ} 09^{\prime} 25^{\prime \prime} \mathrm{N}, 29^{\circ} 37^{\prime} 42^{\prime \prime} \mathrm{E}\right)$.

Short description: Length of females $355-360 \mu \mathrm{m}$, of males 325-330 $\mu \mathrm{m}$. Ds-1 on AD, ds-2 on OC, ds-3,4 on PD. AD of female $130 \mu \mathrm{m}$ long, $95 \mu \mathrm{m}$ wide. Its shape like "horse shoe". OC of female $100 \mu \mathrm{m}$ long, $50 \mu \mathrm{m}$ wide, each with 2 cornea and eyespot. PD of female $125 \mu \mathrm{m}$ long, $100 \mu \mathrm{m}$ wide, twothree rosette pores wide in most of their lenght. $A E$ of female $112 \mu \mathrm{m}$ long, $212 \mu \mathrm{m}$ wide. GA of female $162 \mu \mathrm{m}$ long, 112 $\mu \mathrm{m}$ wide. PE of female $162 \mu \mathrm{m}$ long, $63 \mu \mathrm{m}$ wide. Gnathosoma $88 \mu \mathrm{m}$ long, $50 \mu \mathrm{m}$ wide. Total palp length of females $63 \mu \mathrm{m}$. Telofemur I ventrally with one spine seta ( $25 \mu \mathrm{m}$ long), dorsally with 3 spine setae (Figs. 3, 4, 13 \& 14).

Distribution: This species was described by Viets (1940) for the first time from Adriatic Sea (Croatia-Rovinj and Split). Later on, it recorded from Tyrrhenian Sea (Livorno) by Morselli and Mari (1985). After 32 years, this is the third record of this species from the world.

Remarks: A. conjuncta was originally described by Viets (1940) from the various habitats which was collected from the Adriatic Sea (Croatia-Rovinj and Split). When compared with the original description, our specimens are exhibit all the characters of the type species.

\section{Agauopsis ibssi Bartsch, 1996}

Figs. 5,6,15,16

Material examined: One female, one male from fine sand (12 $\mathrm{m})$ at Kaş $\left(36^{\circ} 09^{\prime} 25^{\prime \prime} \mathrm{N}, 29^{\circ} 37^{\prime} 42^{\prime \prime E}\right)$.

Short description: Length of female $415 \mu \mathrm{m}$, of male $350 \mu \mathrm{m}$. Dorsal plates are punctate and slender. Each rosette pore with wide and shallow, pit-like ostium and, in deeper integumental layers, 6-10 canaliculi. Gland pores inconspicuous. AD of female $150 \mu \mathrm{m}$ long, $175 \mu \mathrm{m}$ wide, very weakly developed $\mathrm{H}$ like costa. OC of female $95 \mu \mathrm{m}$ long, $85 \mu \mathrm{m}$ wide. PD of female $262 \mu \mathrm{m}$ long, $187 \mu \mathrm{m}$ wide. AE of female $162 \mu \mathrm{m}$ long, 300 $\mu \mathrm{m}$ wide. GA of female $162 \mu \mathrm{m}$ long, $150 \mu \mathrm{m}$ wide. PE of female $162 \mu \mathrm{m}$ long, $85 \mu \mathrm{m}$ wide. Gnathosoma $162 \mu \mathrm{m}$ long, $75 \mu \mathrm{m}$ wide. Palps slender, total palp length of female $87 \mu \mathrm{m}$ (Figs. 5, 6, 15 \& 16).

Distribution: Records of this species are presented only from Black Sea (Crimea, Sevastopol) (Bartsch, 2004).

Remarks: $A$. ibssi is distinguished from the $A$. brevipalpus by the following characters: PD is uniformly porose, tarsus I and the spines of leg I are longer than $A$. brevipalpus. The two species also differ in their habitats, $A$. brevipalpus lives 
amongst dense scrubs of algae whereas $A$. ibssi is psammophilous (Bartsch, 1996).

\section{Agauopsis nonornata Bartsch, 1999}

Figs. $7,8,17,18$

Material examined: Two females from detritius riched sediment with Posidonia oceanica $(12 \mathrm{~m})$ at Bilem Beach (3651'17"N, 3044'38"E).

Short description: Length of females $350-385 \mu \mathrm{m}$. AD of female $145 \mu \mathrm{m}$ long, $110 \mu \mathrm{m}$ wide with a small dome shaped areola posterior to frontal spine on $A D$. Costae on $A D$ and $P D$ with polygons, each polygon with alveolus, about $3 \mu \mathrm{m}$ wide. OC of female $85 \mu \mathrm{m}$ long, $25 \mu \mathrm{m}$ wide, each with 2 corneae, posterior portion with small cauda. PD of female $195 \mu \mathrm{m}$ long, $135 \mu \mathrm{m}$ wide. AE of female $125 \mu \mathrm{m}$ long, $212 \mu \mathrm{m}$ wide, garland-like areolae on AE. GA of female $137 \mu \mathrm{m}$ long, $112 \mu \mathrm{m}$ wide. PE of female $125 \mu \mathrm{m}$ long, $37 \mu \mathrm{m}$ wide. Gnathosoma $100 \mu \mathrm{m}$ long, $63 \mu \mathrm{m}$ wide. Palps 4-segmented, total palp lenght is $45 \mu \mathrm{m}$. Leg I stout and longer than following legs. Basifemur I with prominent distoventral lamella. Telofemur I ventrally with proximal and middle lamellar protuberances equipped with spine (Figs. 7, 8, 17 \& 18).

Distribution: $A$. nonornata had been known only from Galapagos Islands since 1977. In this study, the species is recorded for the first time from Turkey.

Remarks: A. nonornata belongs to the ornata group. This species can be easily distinguished from other Agauopsis species by the presence garland-like arranged porose polygons (garland-like areolae) on $\mathrm{AE}$ and the presence distoventra lamella on basifemur I.

\section{Agauopsis pteropes Bartsch, 1986}

Figs. $9,10,19,20$

Material examined: Three females from detritus-riched sediment with P. oceanica (12 m) at Bilem Beach (36 $51^{\circ} 17^{\prime \prime} \mathrm{N}$ $\left.30^{\circ} 44^{\prime} 38^{\prime \prime E}\right)$.

Short description: Length of females $350-385 \mu \mathrm{m}$. AD of female $145 \mu \mathrm{m}$ long, $110 \mu \mathrm{m}$ wide, anterior margin of $A D$ with frontal process which is not sharply. OC of female $85 \mu \mathrm{m}$ long, $25 \mu \mathrm{m}$ wide with a pair of cornea. PD of female $195 \mu \mathrm{m}$ long, $135 \mu \mathrm{m}$ wide. AE of female $175 \mu \mathrm{m}$ long, $250 \mu \mathrm{m}$ wide. GA of female $125 \mu \mathrm{m}$ long, $125 \mu \mathrm{m}$ wide. PE of female $150 \mu \mathrm{m}$ long, $62 \mu \mathrm{m}$ wide. Gnathosoma $100 \mu \mathrm{m}$ long, $75 \mu \mathrm{m}$ wide. Total palp lenght is $63 \mu \mathrm{m}$. Leg I stout and longer than following legs.

Distribution: This species was found first time from Gulf of Lion (France-Mediterranean Sea). This is the second record for the Mediterranean Sea.

Remarks: This species can be easily distinguished from other Agauopsis species by having fin like cuticular lamellae on telofemura III, IV and tibia III, IV.

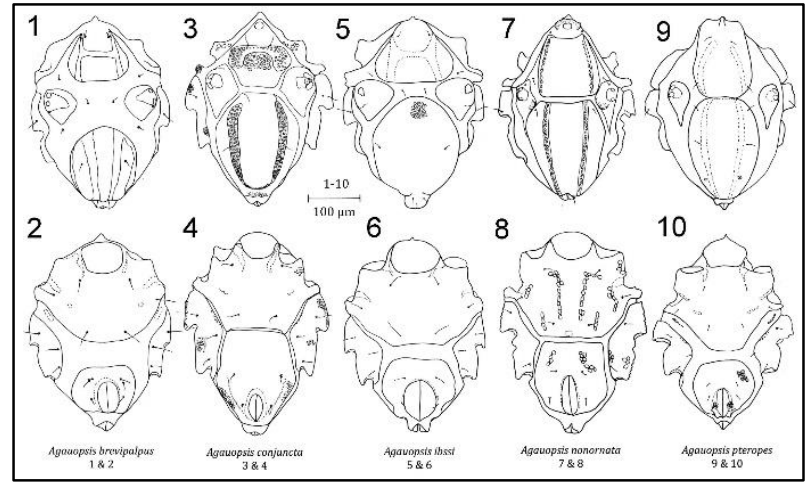

Figures 1-10. Dorsal and ventral views of five female Agauopsis species

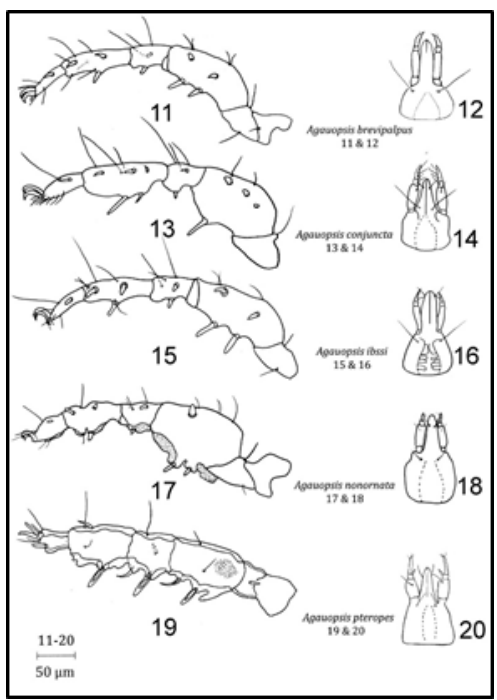

Figures 11-20. Shape of leg I (lateral view) and gnathosoma (ventral view)

\section{DISCUSSION}

So far, only eight species of Agauopsis have been recorded from the Mediterranean Sea. These are: Agauopsis brevipalpus, Agauopsis conjuncta, Agauopsis ibssi, Agauopsis marinovi, Agauopsis microrhyncha, Agauopsis pteropes, Agauopsis spinipes and Agauopsis tricuspis (Trouessart, 1889; Police, 1909; Viets, 1940; Petrova, 1976; Bartsch, 1986;1996 and 1999). Only two records of Agauopsis have been recorded from the Turkish waters up to date. These are: $A$. brevipalpus and $A$. microhyncha. First one reported from Sinop (Black Sea) by Bartsch (2004). The latter reported from Antalya (Mediterranean Sea) by Durucan \& Boyacı (2016). Their distribution and habitats are outlined (Table 1$)$.

The present records of $A$. nonornata brings the total number of known species in the genus Agauopsis from Mediterranean Sea 8 to 9 . With the present study, the number of Agauopsis species in Turkey has raised from 2 to 6 . 
Table 1. List of all Mediterranean Agauopsis species with additional information *This study

\begin{tabular}{|c|c|c|c|}
\hline Species & Distribution & Habitats & References \\
\hline $\begin{array}{l}\text { Agauopsis } \\
\text { brevipalpus }\end{array}$ & $\begin{array}{l}\text { Northeastern Atlantic: Le Croisic (France), UK, Ireland, } \\
\text { Spain, Azores, Canary Islands Mediterranean and Black } \\
\text { Sea: Tunusia; Algeria; Sozopol, Burgas, Anchialo, } \\
\text { Mesemvria (Bulgaria); Rovinj, Split (Croatia); Livorno, } \\
\text { Salento (Italy); Vama Veche, Costinesti, Agigea, Mamaia } \\
\text { (Romania); Caucasian Coast (Russia); Odessa, Crimea, } \\
\text { Sevastapol (Ukraine);Sinop, Antalya* (Turkey) }\end{array}$ & $\begin{array}{l}\text { bryozoan colonies, } \\
\text { phanerogamae, sand, } \\
\text { various algae, Aplysina } \\
\text { aerophoba, Arca noae, } \\
\text { Geodia sp., Ostrea sp. }\end{array}$ & $\begin{array}{l}\text { Trouessart, 1889; Morselli and } \\
\text { Mari, 1982;1985; Bartsch, } 2004\end{array}$ \\
\hline $\begin{array}{l}\text { Agauopsis } \\
\text { conjuncta }\end{array}$ & $\begin{array}{l}\text { Mediterranean Sea: Rovinj, Split (Croatia); Livorno (Italy); } \\
\text { Antalya*(Turkey) }\end{array}$ & $\begin{array}{l}\text { sand, various algae, Arca } \\
\text { noae, Geodia sp., } \\
\text { Cymodosa nodosa (15 } \\
\text { m), Zostera sp. }\end{array}$ & $\begin{array}{l}\text { Viets, 1940; Morselli and Mari, } \\
1985\end{array}$ \\
\hline $\begin{array}{l}\text { Agauopsis } \\
\text { ibssi }\end{array}$ & $\begin{array}{l}\text { Mediterranean and Black Sea: Crimea, Sevastopol } \\
\text { (Ukraine); Antalya* (Turkey) }\end{array}$ & $\begin{array}{l}\text { coarse sand }(5-12 m) \text {, fine } \\
\text { sand }(12 m)\end{array}$ & Bartsch, 1996 \\
\hline $\begin{array}{l}\text { Agauopsis } \\
\text { marinovi }\end{array}$ & $\begin{array}{l}\text { Northeastern Atlantic: Île-Grande (France) } \\
\text { Mediterranean Sea: Italy Black Sea: Crimea, Sevastopol } \\
\text { (Ukraine); Cap Galata (Bulgaria) }\end{array}$ & coarse sand $(45-55 \mathrm{~cm})$ & Bartsch, 1984; 1996; 2004 \\
\hline $\begin{array}{l}\text { Agauopsis } \\
\text { microrhyncha }\end{array}$ & 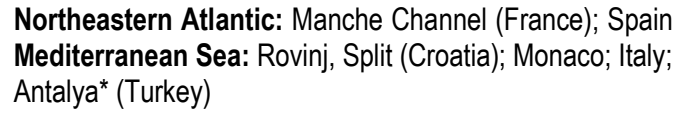 & $\begin{array}{l}\text { algae,sponge and } \\
\text { bryozoan habitat }(58 \mathrm{~m}) \text {, } \\
\text { fine sand }(12 \mathrm{~m})\end{array}$ & $\begin{array}{l}\text { Trouessart, } 1889 \quad \text { Viets, } \\
\text { 1940; André, 1946; Durucan } \\
\text { and Boyacl, } 2016\end{array}$ \\
\hline $\begin{array}{l}\text { Agauopsis } \\
\text { nonornata }\end{array}$ & 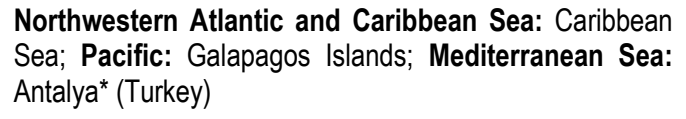 & $\begin{array}{l}\text { intertidal and upper } \\
\text { sublittoral habitats, } \\
\text { P. oceanica }(12 \mathrm{~m})\end{array}$ & Bartsch, 1977;1999 \\
\hline $\begin{array}{l}\text { Agauopsis } \\
\text { pteropes }\end{array}$ & $\begin{array}{l}\text { Northeastern Atlantic: Canary Islands Mediterranean } \\
\text { Sea: Gulf of Lion (France), Antalya* (Turkey) }\end{array}$ & $\begin{array}{l}\text { sediment with detritius } \\
(37 \mathrm{~m}, 45 \mathrm{~m}), \text { P.oceanica } \\
(12 \mathrm{~m})\end{array}$ & Bartsch, 1986 \\
\hline $\begin{array}{l}\text { Agauopsis } \\
\text { spinipes }\end{array}$ & Mediterranean Sea: Naples, (Italy) & algae $(3 m)$ & Police, 1909 \\
\hline $\begin{array}{l}\text { Agauopsis } \\
\text { tricuspis }\end{array}$ & $\begin{array}{l}\text { Northeastern Atlantic: Spain to UK and Ireland } \\
\text { Mediterranean Sea: Adriatic Sea (near Venice) }\end{array}$ & $\begin{array}{l}\text { algae, barnacles, } \\
\text { mussels }\end{array}$ & $\begin{array}{l}\text { Benard, 1962; } \\
\text { Green and MacQuitty, } 1987\end{array}$ \\
\hline
\end{tabular}

\section{ACKNOWLEDGEMENTS}

We are grateful to Dr. Ilse Bartsch (Forschungsinstitut Senckenberg DESY) who kindly gave it to some articles to the first author of the manuscript, correction of Agauopsis ibssi, taxonomic identification of $A$. pteropes and critical reviewing for the manuscript. Special thanks are due to Dr. Matteo Dal Zotto (Università degli Studi di Modena e Reggio Emilia, Department of Life Sciences, Modena, Italy), Dr. Mohamed W. Negm (Department of Plant Protection, College of Agriculture, Assiut University, Assiut-Egypt) and Enes Hasan (Middle East Technical University, Department of Physics, Ankara, Turkey) who kindly sent copies of some articles. This study was financially supported by the Süleyman Demirel University, SDÜ-BAP3973-D2-14 project.

\section{REFERENCES}

André, M., (1946). Halacariens marins. Faune de France, 46, 152 pp. France.

Bartsch, I., (1977). Interstitielle Fauna von Galapagos. XX. Halacaridae (Acari). Mikrofauna des Meeresbodens, 65: 1-108.

Bartsch, I., (1984). Ergänzungen zur Halacariden-Fauna der Bretagne-Küste und Beschreibung einer neuen Art (Halacaridae, Acari). Cahiers de Biologie Marine, 25: 113-122.

Bartsch, I., (1986). New species of the genus Rhombognathus (Acari, Halacaridae), and a key to Mediterranean Rhombognathus. Mesogée, 46: 3-7.

Bartsch, I., (1989). Marine mites (Halacaroidea: Acari): a geographical and ecological survey. Hydrobiologia 178: 21-42. doi: 10.1007/BF00006111

Bartsch, I., (1996). Agauopsis (Acari, Halacaridae) of the Sevastopol area; supplementary notes on taxonomy and ecology. Revue de Suisse Zoologie, 103: 697-712. doi: 10.5962/bhl.part.79969 
Bartsch, I., (1999). Wiederbeschreibung zweier Arten der Agauopsis ornataGruppe (Acari, Halacaridae). Entomologische Mitteilungen aus dem Zoologischen Museum Hamburg, 13: 37-48.

Bartsch, I., (2004). The Black Sea halacarid fauna (Halacaridae, Acari): fauna comparison with the Mediterranean, eastern North Atlantic, North Sea, and Baltic and reflection on its origin. Museum für Naturkunde in Berlin Zoologische Reihe 80, 2: 143-158.

Bartsch, I., (2006). Halacaroidea (Acari): A Guide to Marine Genera, Organisms Diversity \& Evolution, Electronic Supplement, 6: 1-104p. doi: 10.1007/978-3-662-55958-1_5

Bartsch, I., (2009). Checklist of marine and freshwater halacarid mite genera and species (Halacaridae: Acari) with notes on synonyms, habitats distribution and descriptions of the taxa, Zootaxa, 1998: 1-170p.

Benard, F., (1962). Sur une nouvelle espèce d'Acariens marin, Agauopsis tricuspis (superfamille des Prostigmata, famille des Halacaridae). Acarologia, 4: 215-229.

Durucan, F. \& Boyaci, Y.Ö., (2016). First record of Agauopsis microrhyncha (Trouessart, 1889) (Acari: Halacaridae) from the Levantine Sea, Antalya In: Mytilineou,Ch., Akel, N., Babali, N., Balistreri, P., Bariche, M., Boyaci, Y.Ö., Cilenti, C.,Constantinou, C., Crocetta, F., Çelik, M., Dereli, H., Dounas, F., Durucan, F., Garrido, A., Gerovaslileiou, V., Kapiris, K. Kebapçıoğlu, T., Kleitou, A., Krystalas, L., Lipej, L., Maina, P., Marakis, B. Mavric, B., Moussa, R., PeñaRivas, L., Poursanidis, D., Renda, W., Rizkalla, S.I., Rosso, A., Scirocco, T.,Sciuto, F., Servello, G., Tiralongo F., Yapici, S., Zenetos, A. (Eds). Mediterranean Marine Science 17/3, 811 812. Mediterranean Biodiversity Records (November 2016).
Green, J. \& MacQuitty, M., (1987). Halacarid Mites (Arachnida: Acari) Keys and notes for the identification of the species, Synopses of the British Fauna, ed: Kermak, D.M. and Barnes, R.S.K. No:36, The Linnean Society, London, 178p.

Morselli, I. \& Mari, M., (1982). Alacaridi (Acari, Prostigmata) di fondi sabbiosi della Kosta lonica del Salento. Atti della Societa Toscana di Scienze Naturali, Memorie, Serie B, 88, 229-247.

Morselli, I. \& Mari, M., (1985). Ricerche sugli alacaridi delle coste Livornesi. IV. - Osservazioni su alcune specie raccolte su fondi sabbiosi della zona di Piombino. Atti della Societa Toscana di Scienze Naturali, Memorie, Serie B, 91, 201-220.

Police, G., (1909). Alcune nuove specie di Halacaridae del Golfe di Napoli. Archivio Zoologico, Napoli, 3, 409-443.

Petrova, A. (1976). Une nouvelle espèce d'Agauopsis (Prostigmata, Halacaridae) du littoral de la Mer Noire. Chidrobiologija, Sofiya, 4, 67-70

Trouessart, E.L., (1889). Revue synoptique de la famille des Halacaridae. Bulletin Scientifiques de la France et de la Belgique, Série 3, 20, 225-251. doi: 10.5962/bhl.part.28995

Viets, K., (1940). Meeresmilben aus der Adria (Halacaridae und Hydrachnellae, Acari). Archiv für Naturgeschichte, (Neue Folge) 9, 1-135p.

WoRMS Editorial Board 2017. World Register of Marine Species. Available from http://www.marinespecies.org at VLIZ. Accessed 2017-11-25. doi:10.14284/170 